\title{
Keracunan paracetamol pada kucing lokal
}

\author{
Putu Jodie Kusuma Wijaya ${ }^{1}$, Retno Wulansari ${ }^{2} *$, Husnul Hamdi ${ }^{3}$, \\ Arief Purwo Mihardi ${ }^{2}$, Leni Maylina ${ }^{2}$ \\ ${ }^{1}$ Program Pendidikan Profesi Dokter Hewan, Fakultas Kedokteran Hewan, Institut Pertanian Bogor, Bogor \\ ${ }^{2}$ Departemen Klinik, Reproduksi dan Patologi, Fakultas Kedokteran Hewan, Institut Pertanian Bogor, Bogor \\ ${ }^{3}$ Praktisi di Rumah Sakit Hewan Jakarta (RSHJ), Jakarta, Indonesia
}

\begin{abstract}
ABSTRAK: Kucing domestik betina berumur satu tahun bernama Kesi datang ke Rumah Sakit Hewan Jakarta (RSHJ) dengan keluhan wajah yang membengkak. Anamnesa yang didapat dari pemiliknya bahwa hewan terlihat lesu, sehingga pemiliknya memberikan Decolgen ${ }^{\circledR}$ pada Kesi sehari sebelumnya. Kelainan yang paling umum diamati pada pemeriksaan fisik dari kucing adalah: tingkat pernapasan meningkat, pucat-berlumpur selaput lendir, hipotermia, dan takikardia. Tanda-tanda lain adalah depresi, anoreksia, muntah, wajah dan cakar membengkak, air liur, diare, koma dan kematian. Dari temuan klinis dan anamnesa pemilik didapati bahwa hewan mengalami keracunan paracetamol. Prognosa yang didapat dari kasus adalah dubius apabila segera ditangani dan infausta apabila tidak segera ditangani. Pemberian paracetamol pada kucing tidak disarankan karena dapat berakibat fatal pada kucing. Pemberian acetylcysteine pada Kesi bertujuan untuk membantu kucing dalam pembentukan glutathione seluler. Setelah dilakukan pengobatan selama 3 hari, terlihat adanya kemajuan yang dapat diamati dari mukosa yang sudah tidak membengkak dan mukosa sudah tidak berwarna pucat lagi. Setelah 4 hari pengobatan, hewan sudah diperbolehkan untuk dibawa pulang oleh dokter.
\end{abstract}

Kata kunci:

keracunan, paracetamol, kucing

\section{- PENDAHULUAN}

Parasetamol atau acetaminophen adalah obat analgesik dan antipiretik yang populer dan digunakan untuk melegakan sakit kepala, sengal-sengal dan sakit ringan, dan demam (Plumb 1999). Parasetamol digunakan dalam sebagian besar resep obat analgesik dan flu. Meskipun parasetamol aman dalam dosis standar, karena mudah diperoleh, overdosis obat sering terjadi baik sengaja atau tidak sengaja (Rajesh et al. 2017). Berbeda dengan obat analgesik yang lain seperti aspirin dan ibuprofen, parasetamol tidak bersifat antiradang sehingga tidak tergolong dalam obat jenis NSAID. Dalam dosis normal, parasetamol tidak menyakiti permukaan perut atau mengganggu gumpalan darah, ginjal atau duktus arteriosus pada janin (Dorigon et al. 2013).

Acetaminophen dimetabolisme untuk metabolit N-asetilp-benzoquinoneimine (NAPQI) yang sangat reaktif dalam sel dengan aktivitas P450 (Savides et al. 1984). Sebagian besar spesies, termasuk kucing, mayoritas acetaminophen diekskresikan dalam urin sebagai glucoronide dan konjugat sulfat sebagai metabolit tidak beracun. Kucing relatif kekurangan aktivitas enzim glucuronyl transferase sebagai konjugat antara acetaminophen dan asam glukuronik untuk diekresikan (Dorigon et al. 2013). Dosis acetaminophen yang diberikan, kurang dari $3 \%$ dari glukuronida acetaminophen diekskresikan oleh kucing, sementara manusia dan anjing dapat menghilangkan $50-60 \%$ sebagai konjugat glukuronat. Oleh karena itu, acetaminophen pada kucing proporsi yang relatif lebih besar untuk dimetabolisme menjadi senyawa antara reaktif. Persediaan glutathione seluler menjadi cepat habis dalam hati, eritrosit, serta sel-sel lain di seluruh tubuh. Deplesi glutathione menyebabkan sel tidak terlindungi dari efek oksidasi metabolit beracun NAPQI (Savides et al. 1984).

\section{- KASUS}

Anamnesa: Anamnesa dari pemilik bahwa hewan terlihat lesu dan diberikan Decolgen ${ }^{\circledR}$ pada kucing Kesi sehari sebelumnya (Gambar 1). Sinyalemen: Kucing domestik betina berumur satu tahun bernama Kesi datang ke Rumah Sakit Hewan Jakarta (RSHJ) dengan wajah membengkak.

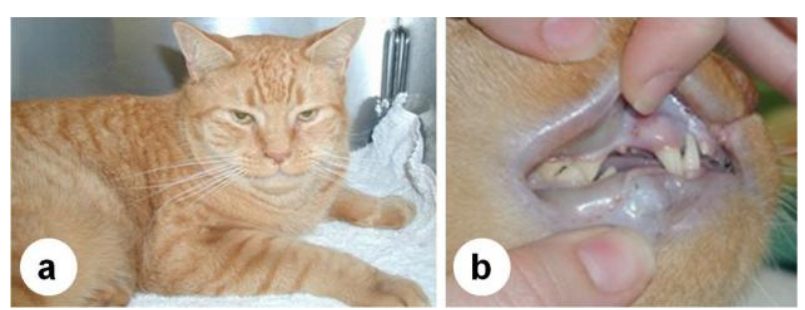

Gambar 1 Kucing Kesi dengan muka bengkak (A) dan bibir bengkak dan kebiruan (cyanosis) (B)

Diterima: 14-02-2018 | Direvisi: 04-03-2018 | Disetujui: 30-03-2018 (C) 2018 CC-BY-SA. Ini adalah artikel Open Access yang didistribusikan berdasarkan ketentuan dari Creative Commons Attribution ShareAlike 4.0 International License (https://creativecommons.org/licenses/by-sa/4.0/). 
Temuan klinis: Kelainan yang paling umum diamati pada pemeriksaan fisik dari kucing berupa tingkat pernapasan meningkat, pucat-berlumpur selaput lendir, hipotermia, dan takikardia. Tanda-tanda lain adalah depresi, anoreksia, muntah, wajah dan cakar membengkak, air liur, diare, koma dan kematian. Anamnesa pemilik dan temuan klinis didapati bahwa hewan mengalami keracunan paracetamol. Prognosa: Prognosa yang didapat dari kasus adalah dubius apabila segera ditangani dan infausta apabila tidak segera ditangani.

\section{- HASIL DAN PEMBAHASAN}

Diagnosis biasanya didasarkan pada riwayat konsumsi, tanda-tanda klinis yang tepat, methe-moglobinemia, Badan Heinz anemia, hemo-globinuria, dan pemeriksaan serum enzim hati. Gejala dapat terjadi lebih cepat atau lambat tergantung pada jumlah tertelan. Gejala keracunan asetaminofen berkembang secara bertahap (Lee et al.1996), yaitu:

1. Tahap 1 (0-12 jam): Gejala-gejala termasuk muntah, kusam, kesulitan bernapas, lesu, anoreksia, kelemahan, gusi berwarna coklat (bukan warna pink normal) dan hipersalivasi.

2. Tahap 2 (12-24 jam): Gejala-gejala termasuk pembengkakan wajah, bibir dan anggota badan, gerakan tidak terkoordinasi, kejang, koma dan potensi kematian.

3. Tahap 3 (lebih dari 24 jam): Gejala yang berhubungan dengan kegagalan hati dan termasuk perut yang menyakitkan, sakit kuning (semburat kuning ke gusi, mata dan kulit).

Pemberian acetylcysteine pada kasus keracunan paracetamol pada kucing bertujuan untuk membantu kucing yang kekurangan glutathione seluler. $N$ - acetylcysteine akan membantu mensubtitusi glutathione yang berkurang akibat mekanisme detoksifikasi NAPQI dengan cara meningkatkan sintesis glutathione (Heard dan Green 2012). Setelah dilakukan pengobatan selama 3 hari, kucing Kesi terlihat adanya kemajuan. Mukosa sudah tidak membengkak dan mukosa sudah tidak berwarna pucat. Setelah 4 hari pengobatan, hewan sudah diperbolehkan untuk dibawa pulang oleh dokter hewan.

\section{- SIMPULAN}

Pemberian paracetamol pada kucing tidak disarankan karena dapat berakibat fatal pada kucing. Setelah dilakukan pengobatan dengan acetylcysteine selama 3 hari, terlihat adanya kemajuan berupa mukosa sudah tidak membengkak dan tidak berwarna pucat lagi. Setelah 4 hari pengobatan, hewan sudah diperbolehkan untuk dibawa pulang.

\section{- INFORMASI PENULIS}

Penulis untuk korespondesi

*RW: rtiwul@gmail.com

Divisi Penyakit Dalam, Departemen Klinik, Reproduksi dan Patologi, Fakultas Kedokteran Hewan, Institut Pertanian Bogor, Bogor, Jalan Agatis, Kampus IPB Dramaga, 16680, Indonesia

\section{- UCAPAN TERIMA KASIH}

Terima kasih kepada Kelompok E Gelombang III Program Pendidikan Profesi Dokter Hewan (PPDH) Tahun 2014-2015.

\section{- PUSTAKA ACUAN}

Dorigon O, de Almeida ADV, da Costa FVA. 2013. Acetaminophen toxicity in cats. Revista de Ciências Agroveterinárias. 12(1): 8893.

Heard K, Green J. 2012. Acetylcysteine therapy for acetaminophen poisoning. Current Pharmaceutical Biotechnology. 13(10): 19171923.

Lee SS, Buters JT, Pineau T, Fernandez-Salguero P, Gonzalez FJ. 1996. Role of CYP2E1 in the hepatotoxicity of acetaminophen. Journal of Biological Chemistry. 271(20): 12063-12067.

Plumb DC. 1999. Plumb's: Veterinary Drug Book. $3^{\text {rd }}$ Ed. Iowa (US): Iowa State University Pr.

Rajesh JB, Mahendran K, Bhanuprakash AG, Lekshmanan A, Choudhary SS, Dixit SK. 2017. Paracetamol toxicity in a cat. International Journal of Livestock Research. 7(2):212-4.

Savides MC, Oehme FW, Nash SL, Leipold HW. 1984. The toxicity and biotransformation of single doses of acetaminophen in dogs and cats. Toxicology and Applied Pharmacology. 74(1): 26-34. 